\title{
Pertumbuhan Gross dan Net Populasi Ternak Sapi di Sulawesi Selatan
}

\author{
BASIR PALY \\ Jurusan Peternakan, Fakultas Sains dan Teknologi, UIN Alauddin Makassar \\ Jl. Sultan Alauddin 36 Samata, Kab. Gowa 92113 \\ email: basirpaly@gmail.com
}

\begin{abstract}
This research aims to know the Gross and the Net population growth of beef cattle the last 5 years (2009-2013) in South Sulawesi. Implemented in four regency, namely, Gowa, Bone, Barru and Enrekang. Site selection was based on the consideration that the four regency are the areas of the development of cattle with a total population of about $45.26 \%$ of the total population who are of South Sulawesi. Type of this research is quantitative survey method. The population of the research was the whole group/cattle farmers in four areas. Then each regency selected four groups as the sample, so that the number of samples that are observed as many as 16 groups. Data collection was done through observation and interviews by using the questionnaire. The observed variables are; (1) the number and type of livestock owned, (2) the number of males and females, (3) the addition of the parent, males and famales from outside the province, (4) sales, cut withholding, and cases of death, and (5) the number of births. The results showed that over the last five years (2009-2013) Gross population growth of beef cattle in South Sulawesi $11.46 \%$ per year, growth above the national average of $10.26 \%$ per year. While the growth of the Net population average at $11.18 \%$ per year, whereas the Net population smaller $(11: 18<11.46)$ from the Gross population. Its main cause is the amount of sales, cut withholding, and cases of death which is not compare with birth rate.
\end{abstract}

Keywords: gross, growth, net, population

\section{PENDAHULUAN}

Ternak sapi memiliki peran strategis dalam upaya pemantapan ketahanan pangan. Ketahanan pangan tercermin dari tersedianya pangan yang cukup (jumlah maupun mutu), aman, merata dan terjangkau oleh masyarakat (Kamaruddin, 2009, Suryana, 2010, Atmo et al, 2010 dan Mukson, 2011). Namun realitasnya, produksi sapi nasional makin menurun, pertanda bahwa peran peternakan sapi terhadap ketahanan pangan masih rendah. Persoalan yang paling mendasar adalah, bagaimana mengupayakan agar produksi pangan hewani ini sebanding dengan kebutuhan yang ada. Selama ini, kebutuhan (demand) daging nasional selalu lebih tinggi dari produksi (supply) yang tersedia, sehingga ketergantungan impor makin meningkat (Tim Redaksi, 2009, Dirjen Pronak, 2010 dan Dirjennak, 2010). Di sisi lain, pertumbuhan populasi atau produksi daging sapi dalam negeri relatif lambat (Ilham et al, 2011).
Gambaran krisis daging sapi setidaknya mulai terjadi sejak Tahun 2001, dimana produksi daging sapi dan kerbau hanya sebesar 382,3 ribu ton, sedangkan konsumsi 423,3 ribu ton (Kementan-BPS, 2010 dan Kementan, 2012). Pertumbuhan volume impor ternak dan daging sapi nasional terus meningkat. Dalam upaya memenuhi kebutuhan tersebut, Indonesia telah tiga kali mengalami mencanangkan program swasembada daging sapi nasional (Kementan, 2012).

Pertama, di Tahun 2000-2005 dengan nama Program Kecukupan Daging Sapi, yang kedua di Tahun 2005-2010 dengan nama Program Percepatan Swasembada Daging Sapi 2010, dan yang ketiga di Tahun 2010-2014 dengan nama Program Swasembada Daging Sapi 2014, yang sampai saat ini juga belum berhasil. Hasil Sensus pertanian Mei 2013 bahkan mencatat jumlah populasi sapi potong 12,68 juta ekor (BPS, 2013), justru menurun 2,14 juta ekor atau $14,43 \%$ sementara sensus 
ternak yang dilakukan BPS pada Juni 2011 tercatat 14,82 juta ekor (Kementan-BPS, 2011). Sulawesi Selatan pada Tahun 1900 merupakan salah satu sentra produksi ternak sapi terbesar di Indonesia setelah Provinsi Jawa Timur. Populasi sapi pada periode tersebut mencapai 1.235.975 ekor di tahun 1992.Kemudian mengalami penurunan selama tahun 2002-2006 sebanyak 2,63\% per tahun (Sonjaya, 2012). Penurunan ini ditengarai karena tingginya angka pemotongan dan pengeluaran ternak ke provinsi lain. Termasuk tingkat kelahiran dan produktivitas ternak yang rendah. Padahal ke depan, permintaan dan konsumsi daging terus meningkat, sejalan dengan pertumbuhan penduduk dan perbaikan pendapatan masyarakat.

Sulawesi Selatan memiliki potensi yang cukup besar untuk pengembangan peternakan sapi potong (Syamsu et al, 2006, Anonymous, 2009, Ifar dan Bambang, 2010). Ditinjau dari sosio-kultural, pemeliharaan ternak sapi telah diusahakan secara turun-temurun oleh masyarakat di provinsi ini. Tersedia dukungan sumber daya lokal, seperti: (1) ketersedian bahan baku pakan dari hasil limbah pertanian, seperti jerami, dedak, dan sejenisnya, (2) ketersedian sarana peternakan yang representatif seperti RPH, pasar hewan, dan Puskewan, (3) infrastruktur pendukung baik jalan, transportasi, pelabuhan laut antar pulau, dan (4) letak geografis yang strategis dalam perdagangan komoditi peternakan di kawasan Timur Indonesia. Namun, tantangan yang dihadapi dalam peningkatan populasi ini antara lain adalah: (1) Rendahnya kelahiran yang tidak sebanding dengan angka penjualan, pemotongan, dan kasus kematian ternak; dan (2) Semakin terbatasnya bibit betina dan pejantan akibat pengeluaran atau perdagangan ke wilayah lain di luar Sulawesi Selatan. Penelitian ini bertujuan untuk mengetahui pertumbuhan Gross dan Net populasi sapi potong 5 tahun terakhir, kurun waktu 20092013 di Sulawesi Selatan.

\section{METODE}

Penelitian ini dilaksanakan di empat kabupaten di provinsi Sulawesi Selatan, yaitu di Kabupaten Gowa, Kabupaten Bone, Kabupaten Barru, dan Kabupaten Enrekang. Pemilihan lokasi ini didasarkan pada pertimbangan bahwa ke empat wilayah tersebut merupakan wilayah pengembangan ternak sapi dengan jumlah populasi sekitar $46.26 \%$ dari total populasi ternak sapi yang ada Sulawesi Selatan.

Jenis penelitian ini adalah kuantitatif. Sedangkan metode yang digunakan adalah metode survei. Populasi atau subyek yang menjadi sasaran dalam studi ini adalah keseluruhan kelompok/peternak sapi yang ada di wilayah penelitian. Setiap wilayah kabupaten dipilih 4 kelompok ternak, sehingga jumlah kelompok sampel yang diamati sebagai unit penelitian sebanyak 16 kelompok. Lokasi kelompok sampel di setiap kabupaten ada yang seluruhnya terletak di satu kecamatan, tetapi ada juga yang terpisah di dua kecamatan yang berbatasan.

Pengumpulan data dan informasi dilakukan melalui pengamatan dan wawancara mendalam dengan menggunakan daftar pertanyaan (kuisioner) yang terstruktur. Kuesioner disusun berdasarkan pertanyaan kunci yang harus digali di lapangan melalui subyek peternak. Priodesasi waktu dari data dan informasi yang dikumpulkan adalah mulai dari Tahun 2008 sampai dengan Tahun 2013. Ada 5 variabel yang diamati dan dianalisis dalam penelitian ini. Yaitu: (1) jumlah dan jenis ternak sapi yang dimiliki, (2) Jumlah betina dan penjantan, (3) Penambahan Induk dan pejantan dari luar wilayah atau provinsi, (4) Penjualan, pemotongan, dan kasus kematian, dan (5) Jumlah kelahiran. Data dari ke 5 varibel ini dianalisis dan interpretasi secara sistimatis. Hasil analisis ini divalidasi dengan data dan informasi yang berasal dari sumber lain, khususnya dari Dinas Peternakan Kabupaten dan Provinsi Sulawesi Selatan. 
HASIL

Tabel 1. Gross Populasi Ternak Sapi Sulawesi Selatan 2009-2013

\begin{tabular}{rrrrrrr}
\hline \multirow{2}{*}{ Tahun } & \multicolumn{2}{c}{ Kelahiran } & \multicolumn{2}{c}{ Pemasukan } & \multicolumn{2}{c}{ Gross Populasi } \\
\cline { 2 - 7 } & Ekor & $\%$ & Ekor & $\%$ & Ekor & R (\%) \\
\hline$(1)$ & $(2)$ & $(3)$ & $(4)$ & $(5)$ & $(6)$ & $(7)$ \\
2009 & 820,221 & $85.63 \%$ & 137,675 & $14.37 \%$ & 957,896 & 0 \\
2010 & 851,532 & $79.96 \%$ & 213,450 & $20.04 \%$ & $1,064,982$ & $11.18 \%$ \\
2011 & 926,903 & $77.61 \%$ & 267,335 & $22.39 \%$ & $1,194,238$ & $12.14 \%$ \\
2012 & $1,023,500$ & $77.03 \%$ & 305,240 & $22.97 \%$ & $1,328,740$ & $11.26 \%$ \\
2013 & $1,142,736$ & $77.30 \%$ & 335,620 & $22.70 \%$ & $1,478,356$ & $11.26 \%$ \\
\hline Rataan & 952,978 & $79.50 \%$ & 251,864 & $20.50 \%$ & $1,204,842$ & $11.46 \%$ \\
\hline
\end{tabular}

Keterangan Tabel:

1. Kelahiran ekor dan \% (kolom 2 dan 3 ) adalah jumlah sapi yang dilahirkan dari induk betina yang ada pada tahun bersangkutan

2. Pemasukan ekor dan \% (kolom 5 dan 6) adalah jumlah ternak yang masuk di wilayah Sulawesi Selatan dari luar provinsi

3. Gross populasi ekor (kolom 6) adalah penjumlahan ternak dari kelahiran dan pemasukan

4. $\mathrm{R}(\%)$ kolom 7 adalah pertumbuhan gross populasi ternak sapi potong kurun waktu Tahun 2009-2013.

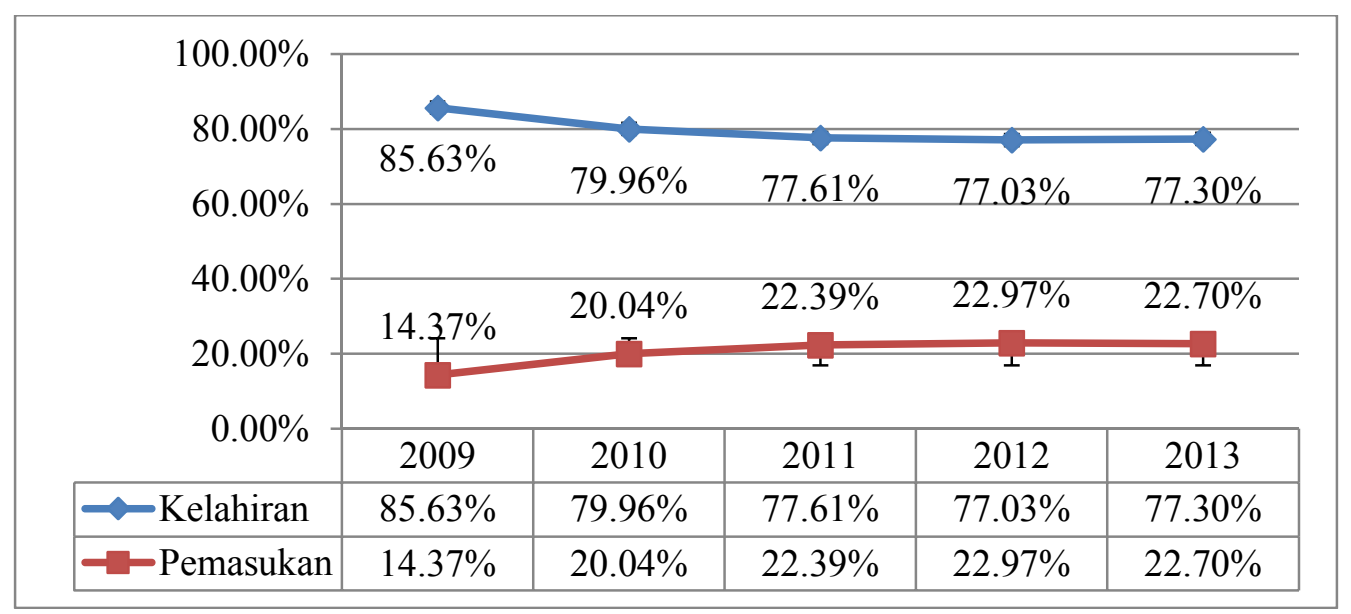

Gambar 1. Trend Kurva Kelahiran dan Pemasukan Ternak

Tabel 2. Net Populasi Ternak Sapi Potong Sulawesi Selatan, 2009-2013

\begin{tabular}{rrrrrrr}
\hline \multirow{2}{*}{ Tahun } & \multicolumn{2}{c}{ Gross Populasi } & \multicolumn{2}{r}{ Jual/Potong/Mati } & Net Populasi \\
\cline { 2 - 7 } & Ekor & $\mathrm{R}(\%)$ & Ekor & $\%$ & Ekor & $\mathrm{R}(\%)$ \\
\hline$(1)$ & $(2)$ & $(3)$ & $(4)$ & $(5)$ & $(6)$ & $(7)$ \\
\hline 2009 & 957,896 & 0 & 222,780 & $23.26 \%$ & 735,116 & 0 \\
2010 & $1,064,982$ & $11.18 \%$ & 249,677 & $23.44 \%$ & 815,305 & $10.91 \%$ \\
2011 & $1,194,238$ & $12.14 \%$ & 287,405 & $24.07 \%$ & 906,833 & $11.23 \%$ \\
2012 & $1,328,740$ & $11.26 \%$ & 327,308 & $24.63 \%$ & $1,001,432$ & $10.43 \%$ \\
2013 & $1,478,356$ & $11.26 \%$ & 355,095 & $24.02 \%$ & $1,123,261$ & $12.17 \%$ \\
\hline Rataan & $1,204,842$ & $11.46 \%$ & 288,453 & $23.88 \%$ & 916,389 & $11.18 \%$ \\
\hline
\end{tabular}

Keterangan:

1. Net populasi ekor (kolom 6) adalah jumlah ternak setelah dikurangi dengan penjualan/pemotongan/kematian pada kolom 4 dan 5 .

2. $\mathrm{R}(\%)$ kolom 7 adalah pertumbuhan Net populasi ternak sapi potong kurun waktu Tahun 2009-2013. 
3. Angka kematian rata-rata $3.05 \%$ per tahun, sedangkan jual/potong rata-rata $20.83 \%$ per tahun

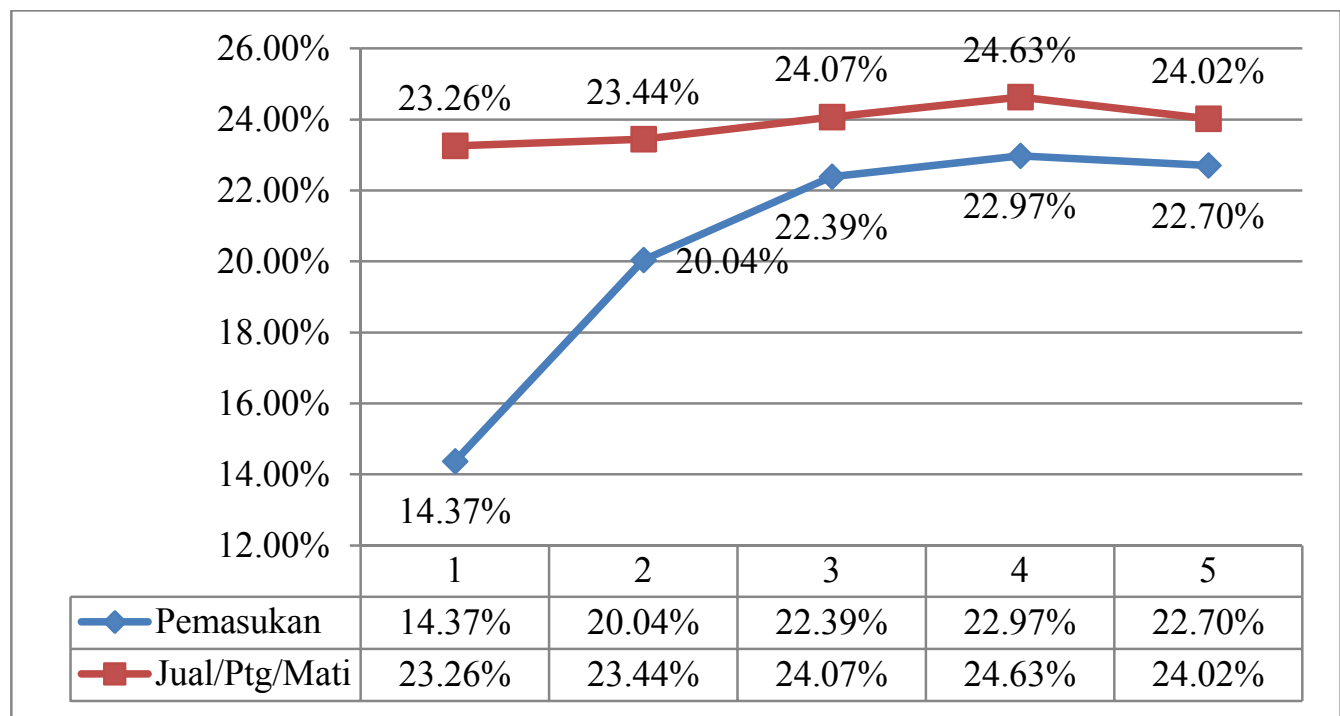

Gambar 2. Kurva Pemasukan dan Penjualan/Pemotongan/Kematian Ternak Sapi

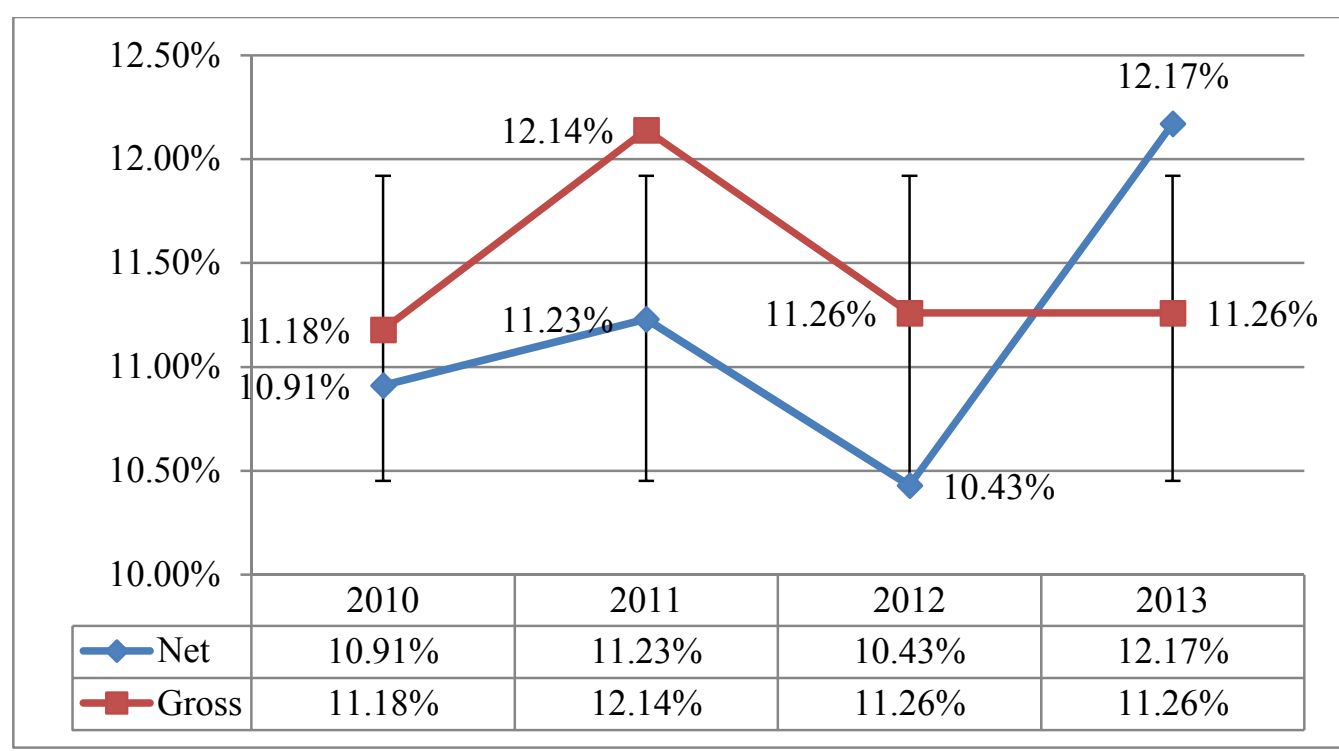

Gambar 3. Kurva Pertumbuhan Gross dan Net Populasi

\section{PEMBAHASAN}

Gross Populasi. Gross populasi adalah penjumlahan antara populasi yang ada dengan kelahiran dan pemasukan ternak dalam periodeyang sama (Dirjennak, 2013). Dikatakan Gross populasi karena belum dilakukan pengurangan atau koreksi terhadap jumlah penjualan, pemotongan, dan kasus kematian ternak. Hasil penelitian menunjukkan bahwa dalam kurun lima tahun terakhir (2009-2013), persentase angka kelahiran rata-rata $79.50 \%$ per tahun. Sementara persentase pemasukan ternak, yang datang dari luar Sulawesi Selatan rata-rata $20.50 \%$ per tahun. Angka kelahiran dan pemasukan ternak inilah yang membentuk Gross populasi. Untuk lebih jelasnya angkaangka tersebut disajikan pada Tabel 1.

Tabel 1 juga menjelaskan bahwa dalam kurun waktu 2009-2013, rata-rata Gross populasi ternak sapi sekitar 1,204,842 ekor dengan pertumbuhan $(\mathrm{R} \%)$ rata-rata $11.46 \%$ per tahun. Pertumbuhan gross populasi terendah (11.18\%) terjadi pada Tahun 2010, sedangkan tertinggi $(12.14 \%)$ terjadi pada Tahun 2011. Setelah itu, pertumbuhan Gross populasi kembali menurun di Tahun 2012 dan 2013 masing-masing $11.26 \%$, sehingga ratarata pertumbuhan $11.46 \%$ per tahun. Meskipun demikian, pertumbuhan Gross 
populasi $11.46 \%$ ini cukup tinggi bila dibanding rata-rata nasional yang mencapai $10.26 \%$ per tahun.

Ada dua faktor yang mempengaruhi pertumbuhan Gross populasi yang dapat diungkapkan dari hasil penelitian ini. Pertama, Tingkat kelahiran. Selama kurun lima tahun 2009-2013, diperoleh tingkat kelahiran ratarata $79.50 \%$. Angka ini cukup tinggi dibanding dengan hasil pencapaian nasional rata-rata $78.65 \%$. Meskipun demikian, patut dicatat bahwa kurva angka kelahiran pada penelitian ini memiliki trend yang menurun. Pada Tahun 2009 angka kelahiran tercatat $85.63 \%$, kemudian berangsur-angsur turun $79.96 \%$ tahun 2010, $77.61 \%$ di Tahun 2011, dan $77.03 \%$ di Tahun 2012. Di Tahun 2013 angka kelahiran mulai bergerak naik, dari $77.03 \%$ menjadi $77.30 \%$, namun perbedaan angka ini tidak seberapa (cukup tipis), hanya selisih $0.27 \%$. Lebih jelasnya dapat disimak pada Gambar 1.

Kedua, Pemasukan ternak. Dalam kurun waktu lima tahun (2009-2013), pemasukkan ternakdari luar Sulawesi Selatan mencapai rata-rata $20.50 \%$ per tahun. Secara aktual, angka pemasuk ternak terbilang tinggi, di atas rata-rata. Kecuali di Tahun 2009 dan 2010 yang hanya $14.37 \%$ dan $20.04 \%$. Sedangkan tiga tahun berikutnya secara berturut-turut berada di atas angka rata-rata $22 \%$ per tahun. Persoalannya adalah angka pemasukan ternak ini trendnya agak linear (mendatar), sementara dalam periode waktu yang sama, trend angka kelahiran menurun. Akibatnya perilaku kedua kurva ini akan mempengaruhi pertumbuhan gross populasi ternak dalam periode waktu tersebut.

Net Populasi. Net populasi adalah hasil pengurangan gross populasi dengan jumlah ternak yang dijual, dipotong, dan yang terkena kasus kematian (Dirjennak, 2013). Dikatakan Net populasi karena secara aktual jumlah ini hidup dan dibudidayakan oleh peternak untuk kepentingan produksi yang lebih lanjut. Dengan kata lain bahwa Net populasi adalah penjumlahan dari populasi aktual ditambah jumlah kelahiran dan pemasukan dikurangi dengan jumlah penjualan, pemotongan, dan kasus kematian.
Hasil penelitian menunjukkan bahwa dalam kurun lima tahun terakhir (2009-2013), Gross populasi tumbuh rata-rata $11.46 \%$ per tahun, sementara Net populasi tumbuh ratarata $11.18 \%$ per tahun. Terdapat perbedaan sekitar $0.28 \%$ dari kedua parameter ini, dalam pengertian bahwa pertumbuhan Net populasi lebih kecil $(11.18<11.46)$ dari Gross populasi.

Penyebab utamanya tentu saja jumlah penjualan, pemotongan, dan kasus kematian yang tidak sebading, atau lebih besar, dengan angka kelahiran, sebagaimana dijelaskan sebelumnya. Akibatnya pertumbuhan Net populasi mengalami penyusutan dari Gross populasi yang ada. Lebih jelasnya dapat dilihat pada Tabel 2.

Tabel 2 juga menjelaskan bahwa setelah tumbuh $12.14 \%$ di Tahun 2011, Gross populasi mulai menurun dengan pertumbuhan $11.26 \%$ pada tahun berikutnya (2012 dan 2013). Selisih pertumbuhan ini cukup berarti, sekitar $0.88 \%$ pe tahun. Penurunan Gross populasi ini, selain dampak dari trend penurunan angka kelahiran dan pemasukan ternak yang telah disajikan pada Gambar 1 sebelumnya. Juga terjadi karena akumulasi jumlah penjualan, pemotongan, dan kematian yang tidak sebanding dengan jumlah pemasukan ternak ke Sulawesi Selatan. Dalam konteks ini, penjualan, pemotongan, dan kematian cenderung menjadikan Net populasi menyusut dari Gross populasi yang ada. Untuk lebih jelasnya, keadaan ini diilustrasikan pada Gambar 2.

Gambar 2 memetakan kurva persentase pemasukan dan penjualan, pemotongan, dan kematian ternak selama kurun waktu lima tahun (2009-2013). Nampak dengan jelas bahwa kurva pemasukan berada di bawah kurva penjualan, pemotongan, dan kematian. Dengan kata lain bahwa penjualan, pemotongan, dan kematian cenderung menguras populasi yang terjadi dari kelahiran baru. Akibatnya Net populasi mengalami pengurangan dari Gross populasi yang ada periode bersangkutan. Secara parsial dapat dijelaskan bahwa perbandingan Gross dan Net populasi pada Tahun 2010 (11.18>10.91), Tahun 2011 (12.14>11.23), Tahun 2012 (11.26>10.43). Khusus Tahun 2013 Net 
populasi lebih besar dari Gross populasi (12.17>11.26). Perbedaan ini dipengaruhi oleh angka kelahiran yang meningkat di Tahun 2013 sebesar $77.30 \%$ dari $77.03 \%$ pada Tahun 2012 sebelumnya, lihat Tabel 1 dan Gambar 1.

Meskipun pada periode yang sama pemasukan ternak mengalami penurunan dari $22.97 \%$ menjadi $22.70 \%$, namun ternyata akumulasi penjualan, pemotongan, dan kematian juga mengalami penurunan dari $24.63 \%$ menjadi $24.02 \%$. Dengan demikian kuat dugaan bahwa yang mempengaruhi angka Net populasi lebih besar dari Gross populasi adalah angka kelahiran. Lebih jelasnya perbedaan atau pun perbandingan Net dan Gross populasi selama lima tahun (2009-2013) diilustrasikan pada Gambar 3. Berdasarkan Gambar 3, menunjukkan bahwa dari Tahun 2009-2012 kurva Net populasi berada di bawah kurva Gross populasi. Namun pada tahun 2013 kurva Net berada di atas kurva Gross populasi. Berdasarkan hasil analisis, perbedaan ini lebih disebabkan oleh angka kelahiran yang meningkat di Tahun 2013 sebesar $77.30 \%$ dari $77.03 \%$ pada Tahun 2012 sebelumnya. Bukan oleh penurunan penjualan, pemotongan, dan kematian, juga bukan oleh penurunan angka pemasukan ternak dari provinsi lain.

Implikasi Penelitian. Dalam jangka panjang perbedaan ini akan menjadi normal kembali. Penyebabnya adalah siklus populasi, dimana Net populasi akan menjadi Gross populasi pada tahun berikutnya. Selanjutnya Gross populasi akan dikoreksi oleh angka pemasukan ternak, penjualan, pemotongan, dan kematian sebelum sampai kepada Net populasi pada periode tahun yang sama. Dengan demikian, maka implikasi penelitian ini adalah: Pertama, pertumbuhan populasi ternak sapi akan mengalami peningkatan melalui angka kelahiran, tanpa harus meningkatkan angka pemasukan ternak dari provinsi lain. Kedua, dengan peningkatan angka kelahiran, maka jumlah sapi yang dijual dan dipotong juga meningkat. Sehingga berdampak pada peningkatan pendapatan dan kesejahteraan peternak sebagai pemilik. Peningkatan angka penjualan dan pemotongan ini juga tidak akan berpengaruh terhadap penurunan Net populasi. Ketiga, jika angka kematian yang jumlahnya rata-rata $3.05 \%$ per tahun dapat ditekan atau diturunkan, maka penjualan, pemotongan dan Net populasi akan meningkat lebih tinggi lagi.

Pertumbuhan populasi (Gross dan Net), peningkatan penjualan dan pemotongan merupakan upaya yang harus terus dilakukan. Sampai saat ini, kebutuhan daging sapi selalu lebih besar dari produksi, sehingga impor sulit dihindari. Tingkat konsumsi protein hewani di Indonesia pada tahun 2011 masih sekitar 4,7 gram per orang per hari (Sydryanto et al, 2010 dan Yusdja, et al, 2011). Angka ini sangat rendah bila dibandingkan dengan Malaysia, Thailand, dan Filipina yang rata-rata 10 gr/orang/hari. Sementara Korea, Brasil, dan China sekitar 20-40 gram/orang/hari. Konsumsi protein hewani negara-negara maju seperti Amerika Serikat, prancis, Jepang, Kanada, dan Inggris telah mencapai 50-80 gr/kapita/hari. Sejauh ini kebutuhan daging sapi nasional belum bisa sepenuhnya mengandalkan peternakan sapi domestik yang dikelolah oleh RT peternak. Meskipun lebih dari $90 \%$ populasi ternak sapi dipelihara oleh petani/peternak, namun sejak lama mereka terperangkap dalam skala usaha yang kecil (Dirjennak, 2010). Apabila pertumbuhan populasi ini dapat ditingkatkan, seiring dengan peningkatan penjualan dan pemotongan ternak, maka pedapatan peternak juga akan lebih baik dari sebelumnya. Minat peternak dalam budidaya ternak sapi pun semakin tinggi. Hal ini sejalan dengaan program swasembada daging sapi nasional yang sampai saat ini belum juga berhasil. Program ini bertujuan memenuhi konsumsi daging sapi masyarakat yang berasal dari sumber daya lokal (peternak) sebesar 90\%, dan tinggal 10\% disisakan untuk impor baik sapi bakalan maupun daging. Operasionalisasi dari program ini adalah peningkatan produksi sapi lokal, yang ada di peternak, hingga menutupi $90 \%$ dari kebutuhan daging nasional.

\section{KESIMPULAN}

Kesimpulan dari hasil penelitian ini adalah bahwa selama lima tahun terakhir 
(2009-2013) Gross populasi ternak sapi di Sulawesi Selatan tumbuh rata-rata $11.46 \%$ per tahun, di atas pertumbuhan rata-rata nasional yang $10,26 \%$ per tahun. Pertumbuhan Gross populasi di Sulawesi Selatan ini dominan dipengaruhi oleh angka pemasukan ternak ketimbang angka kelahiran.

Pertumbuhan Net populasi rata-rata $11.18 \%$ per tahun, dimana Net populasi lebih kecil $(11.18<11.46)$ dari Gross populasi. Penyebab utamanya adalah akumulasi jumlah penjualan, pemotongan, dan kasus kematian yang tidak sebading, atau lebih besar, dari angka kelahiran. Peningkatan pertumbuhan Gross dan Net populasi ini sejalan dengaan program swasembada daging sapi nasional yang bertujuan untuk meningkatkan produksi sapi lokal hingga mencapai $90 \%$ dari total kebutuhan dalam negeri.

\section{DAFTAR PUSTAKA}

Atmojo SM, Syarief D, Sukandar dan Latifah M. 2010. Pengembangan Model Identifikasi Keterjaminan Pangan di Propinsi Jawa Timur dan Nusa Tenggara Timur. Media Gizi dan Keluarga. No. XIX (2): 1-16.

Dirjen Pronak (Produksi Peternakan Deptan). 2001. Buku Statistik Peternakan. Jakarta: Direktorat Jenderal Bina Produksi Peternakan Departemen Pertanian RI

Ditjennak. 2010. Blue Print Program Swasembada Daging Sapi. Ditjennak. Jakarta: Kementerian Pertanian

Hermanto, Swastika, Dewa KS. 2011. Penguatan Kelompok Tani: Langkah Awal Peningkatan Kesejahteraan Petani. Botani: Pusat Sosial Ekonomi dan Kebijakan Pertanian.

Ifar dan Bambang AN. 2010. Potensi dan Prospek Usaha Peternakan Sapi Potong di Kawasan Timur Indonesia (KTI) Dalam Kerangka Pengembangan Kawasan Ekonomi Terpadu (KAPET). Semiloka Strategi Pengembangan KAPET di Kawasan Timur Indonesia dalam Menghadapi Era Global, 5-6 Juli. Semarang: Universitas Brawijaya.
Ilham N, Basuno E, Sedjati WK, Ashari S. Nuryanti FB, Dabukke, dan Elizabeth R. 2011. Keragaan, Permasalahan dan Upaya Mendukung Akselerasi Program Swasembada Daging Sapi. Laporan Hasil Penelitian. Pusat Sosial Ekonomi dan Kebijakan Pertanian. Jakarta: Badan Penelitian dan Pengembangan Pertanian.

Kamaruddin A. 2009. Sumbangan Pangan Hasil Ternak untuk Gizi Masyarakat. Prosiding Kursus Penyegar Ilmu Gizi serta Konggres IV Pergizi-Pangan Indonesia, Jawa Barat.

Kementan-BPS. 2011. Rilis Akhir Populasi Sapi Potong dan Kerbau (PSPK) 2011. Kementan-BPS.

Kementan. 2012. Cuplikan Blue-Print Swasembada Daging Sapi Nasional 2014. Jakarta: Kementan RI. hal 1-12.

Mukson EP, Ekowati T dan Setiadi A, 2011. The Effect of Supply and Demand Factors to Livestock Food Security in Central Java). Journal of Animal Agricultural Socio-economics. vol 1 (1):1.

Sonjaya H. 2012. Mengkaji Program Sejuta Ekor Sapi di Provinsi Sulawesi Selatan. http://saintis-akademis.blogspot.com. Diakses tanggal 24 Juni 2012.

Sudaryanto T, Sayuti R dan Soedjana TD. 2010. Pendugaan Parameter Permintaan Hasil Ternak di Beberapa Propinsi Sumatera dan Kalimantan. Jurnal Penelitian Peternakan Indonesia. vol 1 (2): 22-35.

Suryana A. 2010. Ketahanan atau Kemandirian Pangan. Dalam: Kemandirian Pangan Menuju Ketahanan Pangan Berkelanjutan. Jakarta: Kerjasama Badan Bimas Ketahanan Pangan Departemen Pertanian dengan Harian Umum Suara Pembaruan.

Syamsu JA, Sofyan LA, Mudikdo K, Gumbira SE, dan Laconi EB. 2006. Analisis potensi limbah tanaman pangan sebagai sumber pakan ternak ruminansia di Sulawesi Selatan. Jurnal Ilmiah Ilmu-ilmu Peternakan. vol VIII (4).

Tim Redaksi. 2009. Pedoman Umum Gerakan Pencapaian Populasi Sapi Sejuta Ekor di 
Sulawesi Selatan. Makassar: Dinas Peternakan dan Kesehatan Hewan.

Yusdja Y, Sayuti R, Winarso B, Sadikin I dan Muslim C. 2011. Pemantapan Program dan Strategi Kebijakan Peningkatan
Produksi Daging Sapi. Bogor: Pusat Penelitian dan Pengembangan Sosial Ekonomi Pertanian, Departemen Pertanian. 